\title{
Profiling the Factors Affecting the Successful Implementation of Green Supply Chain Management in Industrial Sector in Egypt
}

\author{
Prof Dr.Samir Allam \\ Mohammed Mahmoud Kamel \\ Hassan Mohamed Hussien
}

Abstract - the main purpose is to profile the main factors that affect the successful implementation of GSCM approach in Textile industry in Egypt.

Keywords-GSCM, SCM, Green Manufacturing, Green Marketing

\section{Introduction}

Supply chain management has been introduced to the world since several decades; since then it has gained increasing attention from authors. Sarkis (2003) mentioned that the importance of studying SCM has increased over time and during the last years many updates and trends were added like, green, lean, agile and global supply chain. SCM definition has been introduced by many authors.

\section{Green Supply \\ Chain Management Evolution}

Being green became a part of the culture of developed countries manufacturer. They are no more considering it as unnecessary cost. Zhu et al. (2005) supported the idea of positive economic impact of GSCM, and they mentioned that in order to successfully implement GSCM in Japan, companies are in need to create what is called "win - win " situation, which means that the society will benefit the positive environmental effect and the company will benefit the positive financial and economic benefits resulting from saving cost, material and energy. They also claimed that government has a significant role in supporting this "win win" situation by using both regulations and incentives.

\section{Prof. Samir Allam}

Faculty of commerce/Cairo University

Egypt

Mr.Mohammed Mahmoud Kamel

Faculty of commerce/Cairo University Egypt

Mr. Hassan Mohamed Hussien

Faculty of commerce/Cairo University

Egypt

\section{GSCM in Different Settings (Developing vs. Developed)}

There is no doubt that GSCM implementation is much harder in developing countries than developed, due to many factors reasons like: Cultural, Economic, infra-structur Zhu et al. (2004) Mentioned that developed and developing countries can be described based on some factors. These factors include economic factors, level of industrialization and human development index (HDI), thus most of developed countries are industrial countries, and they are believed to deal with lots of environmental issues and many problems due to their economic development. It has been argued by most of authors that the GSCM implementation in developed countries is different than what exists in developing countries. Differences include drivers and conditions that led to successful implementation, barriers that those companies are facing. Even though Zhu and Sarkis (2004) claimed that drivers and pressures are the same but their effect vary from a country to another.

\section{A. GSCM in Developed countries:}

Zhu et al. (2004) Mentioned that developed and developing countries can be described based on some factors. These factors include economic factors, level of industrialization and human development index (HDI), thus most of developed countries are industrial countries, and they are believed to deal with lots of environmental issues and many problems due to their economic development. It has been argued by most of authors that the GSCM implementation in developed countries is different than what exists in developing countries.

Zhu and Quanhu (2004) conducted a research to examine what leads to GSCM implementation in developing countries, they found that GSCM implementation is highly related to the level of employees skills and knowledge and to which extent can they accept a new technology, and the level of internal training and the management ability to shift from traditional manufacturing system green manufacturing system.

\section{B. GSCM in Egypt:}

The As a developing country, Egypt is facing a continuous pressure due to rapid economic growth. Turning to industrial economy was one of the main tools to achieve this economic development in Egypt. According to the report of Egyptian 
Environmental Affairs Agency (EEAA) in 2012 the industrial sector in Egypt represented 34\% of GDP in 2003 and employed about $20 \%$ of the active labor power. May be this industrial revolution in Egypt helped in achieving an economic growth, but there is no doubt that it harmed our environment. We can't just claim that industry is the main reason of pollution, as for example Germany, Japan and UK are leading industrial countries and they succeeded to protect their environment. There are mainly two reasons behind the negative effect of industry on environment in Egypt; the first reason is the migration of heavy polluting industries to Egypt. The second reason is the wrong practices of most of manufacturers in Egypt.

\section{Benefits \\ of \\ GSCM implementation:}

There are several studies that explored the benefits of GSCM implementation. one of the most important studies about benefits of GSCM implementation, is the study of Lamming and Hampson (2000) they identified ten benefits of GSCM implementation, they were as follow: target marketing, sustainability of resources, lowered costs/increased efficiency, product differentiation and competitive advantage, competitive and supply chain pressures, adapting to regulation and reducing risk, brand reputation, return on investment, employee morale, and the ethical imperative.

Bowen et al. (2001) stated that organizations will adopt green supply chain management practices if they identify that this will result in specific financial and operational benefits. Thus, there is a clear research need to establish the potential link between green supply chain initiatives and increased competitiveness and enhanced economic performance, to provide an impetus for organizations to green their supply chains.

\section{v. Barriers of GSCM implementation :}

There are obstacles to implement GSCM for both small and large companies. These obstacles were identified in several studies. Scott et al. (2001) conducted a survey regarding obstacles faced by industry in the application of the concepts of industrial ecology. Results showed that the top obstacles were lack of capital investment (40\%), followed by lack of adequate information (39\%), lack of access to technical expertise (34\%), lack of trained personnel (30\%), current legislation (27\%), and company policies $(24 \%)$.

\section{vi. Factors affecting GSCM implementation}

This section discusses the main factors and drivers affecting the successful implementation of GSCM, Zhu et al. (2005) conducted a research to explore the drivers that affect the implantation of GSCM, and how do these factors affect the organization practices and to which extent the overall performance will be affected, Results showed that regulatory, competitive, and marketing pressures and drivers were important factors that increased Chinese companiese environmental awareness, but they found also that the importance of these factors differ from a country to another as they compared the rank of factors' importance in China against USA and they found that except for regulations, the rank is different. In $2007 \mathrm{Zhu}$ and Sarkis (2007) supported their results and surveyed 341 Chinese manufacturers to examine the relationships between GSCM practice, environmental and economic performance, they found that Chinese companies are facing a pressure from different stake holders (Market \& Government) to shift to green practices and implement GSCM.

\section{A. Regulation:}

\section{B. Suppliers}

Zhu and Geng (2001) mentioned that the suppliers can adapt their system to provide companies with green supplies but this depends on the relationship between the company and suppliers, as strong relation with suppliers will motivate suppliers to invest time and money to change to green. Sarkis (2003) supported this idea and also mentioned that suppliers are willing to shift into green system or adapt a new technology if one or some of their key customers are willing to do the same, on the other hand small and medium business are facing a serious problem in finding suppliers that are willing to adapt new technology or modify their systems to serve them. Carter et al. (2001) Claimed that the role of suppliers is much more than providing the company with raw material and resources, but also they can support the company through providing valuable ideas. They also found that, in some cases the indirect impact of suppliers can be superior to its direct impact on GSCM implementation. Market:

\section{Internal factors \& internal Management}

Many authors suggested that top management support plays a very important role in shaping organization values and directions, many authors like Burgess (1998), Carter, Kale and Grimm (2000), Zhu and Sarkis, (2004), Simpson et al. (2007) considered top management support as a critical factor for GSCM successful implementation. Christopher and Lee (2004) claimed that sometimes top management resistance to implement any new initiative may be a problem that faces GSCM implementation specially if it requires sever modification in the production system and in the purchasing policy of the organization,

\section{vii. Green Supply Chain Implementation Practices}

The GSCM covers wide areas of practices starting from green purchasing to waste management, and the successful implementation of GSCM requires integration between the components of the supply chain, this integration can be expressed as a flow of material, information and technology between suppliers, manufacturers and customers (Zhu \& Sarkis, 2006). 


\section{A. Green Purchasing:}

Qinghua et al. (2006) claimed that green purchasing seems to get significant attention within leading companies in developed countries. However, developing countries companies' practices are still in the early stages, lagging behind practices in developed countries. For example, many enterprises from developed countries evaluate not only their direct suppliers but also second-tier suppliers (suppliers' suppliers).

\section{B. Eco-Design}

Zhu and Sarkis (2006) identified Eco-design as: design of products for reduced consumption of material, energy, reuse, recycle, recovery of material components parts, and it design for product to avoid or reduce use of hazardous products and/or their manufacturing process Lewis et al. (2001) claimed that no matter where in the product life cycle lies, most of the environmental influence is 'locked' into the product at the design stage when materials and processes are selected and product environmental performance is largely determined .Since much of the environmental impacts are associated with packaging and use of products, the supply chain is implicated, as is design. Eco-design (and design for the environment (DFE) is a helpful, emerging tool to improve companies' environmental performance by addressing product functionality while simultaneously minimizing lifecycle environmental impacts. The success of eco-design requires the internal cross-functional cooperation among the entire company and the external cooperation with other partners throughout the supply chain.

\section{Investment Recovery \& Reverse logistics:}

Khiewanavawognsa (2011) Identified Investment recovery practices as "green practices that involve regaining benefits from existing investment, previously considered waste ", generally the main source of revenues for any company is the sales of final products and services. But one of the main issues of GSCM is to reduce the level of waste and also to design products that produce wastes that can be easily recycled or can be used in another industry. As an example for such practices most of cement factories have shifted their technology from liquid to dry technology that generates massive quantities of bypass dust that can be used in producing cement blocks. (Deif, 2011)

\section{Reverse Logistics:}

Gupta et al. (2013) Identified reverse logistics as "the process where a manufacturer accepts previously shipped products from the point of consumption for possible recycling and/or re-manufacturing". They claimed that the reverse logistics activities of an organization are also directly impacted by Customers, suppliers, competitors, and government agencies. The concept of reverse logistics can't be considered as a totally new concept, to according

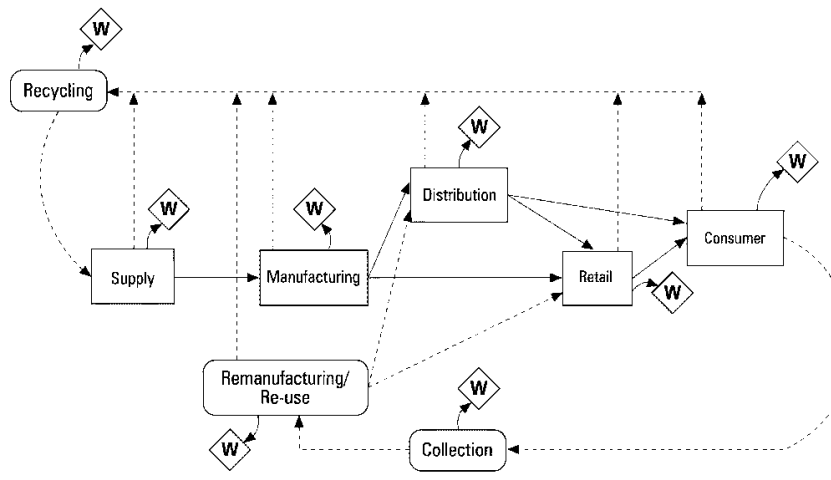

Ker W) Waste (or disposed) materiak

Figure 1. Flow Chart of Re-Manufacturing and Recycling

(Source: Beamon, 1999)

\section{E. Green Manufacturing}

The term green manufacturing is has a different meanings for different people, usually based on their discipline, position, training and many other factors. Green Manufacturing can be defined as production processes which use inputs with relatively low environmental impacts, are highly efficient, and generate little or no waste or pollution. Green Manufacturing can lead to lower raw material costs, production efficiency gains, reduced environmental and occupational safety expenses, and improved corporate image ( Ninlawan et al. 2010). Becoming green should be considered to be a journey, not a destination or static gate. Green manufacturing is considered as a key component of operating sustainable business that helps managers to uncover hidden value for business, while creating value for environment, stake holders and the greater community in order to apply green manufacturing business needs to apply lean, six sigma and other process improvement should be used, to obtain the required performance improvements. (Robert, 2008)

\section{F. Green Marketing}

Green marketing includes environment-friendly packaging, environment-friendly distribution and so on. They are all initiatives that might improve the environmental performance of an organization and its supply chain (Rao, 2003). Management of wastes in green marketing such as reverse logistics and waste exchange can lead to cost savings and enhanced competitiveness (Rao, Greening the supply chain: a new initiative in Sout East Asia, 2002)

\section{viii. GSCM Performance}

Bai and Sarkis (2010) stated that many managers consider environmental management as compliance with regulations while evaluating tradeoffs between environmental and economic performance. However, some anecdotal evidence showed that substantial environmental management performance leads to lower manufacturing costs by eliminating waste (Gilbert, 2001). Numerous studies have tried to find the relationship between strategies and environmental performance.

In 2011, (Zhu,2011) carried out a research to analyze the relationship between the GSCM implementation 
and the performance, he found that the overall effect of GSCM implementation will be positive only in case of successful implementation, he categorized the outcomes of GSCM implementation into four main groups (environmental, economic, cost reduction and intangible outcomes)

\section{A. Financial Performance:}

Economic performance is typically the most important driver for enterprises that wish to implement environmental management practices, especially for enterprises in developing countries such as China. It has been argued that success in addressing environmental issues may provide new opportunities for competition, and new ways to add value to core business programs. Bowen and Lamming (2006) Suggest economic performance is clearly not being reaped in short-term profitability and sales performance. Despite this, there is evidence to suggest that proactive GSCM approaches can prepare enterprises for superior longer term performance through improved management of environmental risks and the development of capabilities for continuous environmental improvement.

\section{B. Operational performance}

There exist two contrasting views about the relationship between environmental practices and operational performance. The first viewpoint argues that many managers believe that environmental management consists simply of compliance with regulations, and that a trade-off exists where increased level of environmental management results in increased cost and low flexibility.

The second viewpoint is supported by a body of research that suggests a positive relationship between environmental practices and operational performance. Zhu et. al, (2007) claimed that the positive effect on operational performance can be determined through certain measures like: (1) Increase amount of goods delivered on time. (2) Decrease inventory levels. (3) Increase scrap rate. (4) Promote products' quality. (5) Increased product line. (6) Improved capacity utilization.

\section{Environmental performance}

Bowen and Lamming, (2006) claimed that both developing and developed countries economy continues to grow and they are facing huge pressures in the area of energy conservation and emission reduction. Green supply chain management can serve as a significant tool to realize "Green transformation". In the long run, green supply chain management - which takes environmental protection and energy conservation into account during the life cycle of production from design, to resource extraction to manufacturing, marketing and recycling or end-of-life management - will not only reduce environmental impact but also optimize resource allocation. Figure 2 illustrates the proposed mode for the paper.

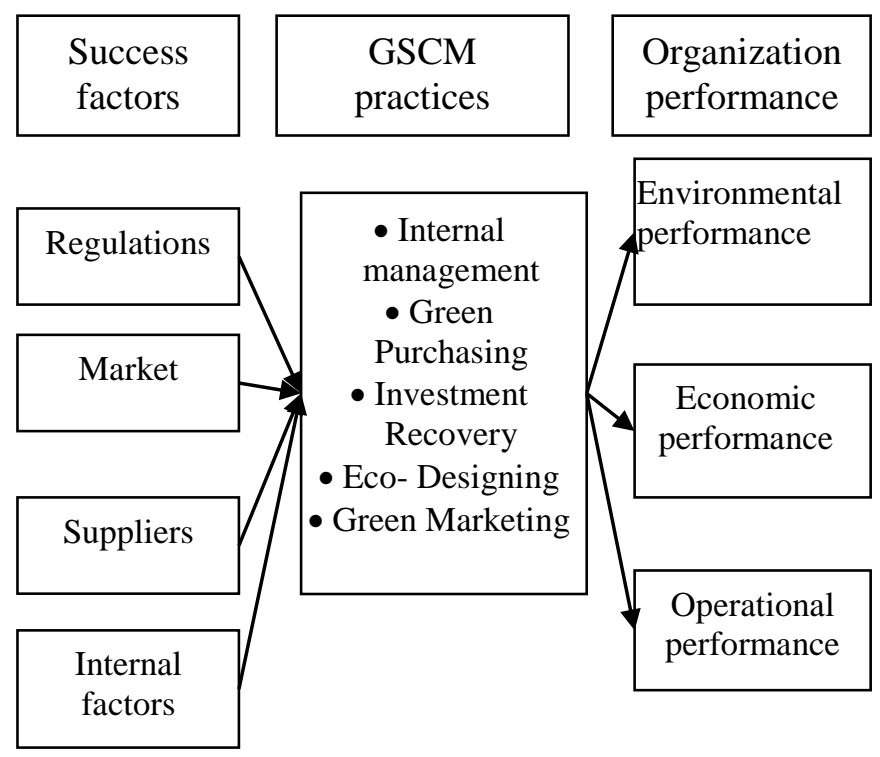

Figure 2: Proposed Model

\section{Research Development}

Hypotheses

The relationships were supported by the exploratory work done Ten hypothesis were resulted as follows;

H1: Market has a positive relationship with Green Supply Chain Practices.

H2: Internal factors have a positive relationship with Green Supply Chain Practices.

H3: Suppliers Involvement has a positive relationship with Green Supply Chain Practices.

H4: Governmental regulations have a positive relationship with Green Supply Chain Practices.

H5: Green Supply Chain Practices have a positive relationship with financial performance

H6: Green Supply Chain Practices have a positive relationship with environmental performance.

H7: Green Supply Chain Practices have a positive relationship with operational performance.

\section{ix. Methodology}

\section{A. Research population:}

According to Support for Environmental Assessment and Management (SEAM) project; 2011 and Zhu (2010) pollution of textile industry is caused mainly by the stages of manufacturing (Spinning, weaving, dyeing, printing and finishing) wastes resulted from readymade garment and Tricot clothes are solid wastes that don't have heavy effect on environment like air emissions and water pollution caused by different production stages. Sample type: Non-probability, judgmental sample.

B. Sample size: as the population targeted is between $460-480$, and the right sample size is 210 sample units. Uma Sakran (2010) also mentioned that in case of 
Proc. of the Fourth Intl. Conf. Advances in Social Science, Economics and Management Study- SEM 2016 Copyright (C) Institute of Research Engineers and Doctors, USA .All rights reserved.

ISBN: 978-1-63248-094-1 doi: 10.15224/ 978-1-63248-094-1-56

stratified sample the sample sub sectors should reflect the diversity of the population, that's why questionnaires were distributed as follow : 128 spinning \& weaving company counts for $61 \%$ of sample size and 82 finishing and printing company counts for $39 \%$ of the sample.

\section{Descriptive Statistics:}

Table 2: Summary of descriptive statistics

\begin{tabular}{|c|c|c|c|c|}
\hline & Frequency & Percent & \begin{tabular}{|l} 
Valid \\
Percent
\end{tabular} & $\begin{array}{l}\text { Cumulative } \\
\text { Percent }\end{array}$ \\
\hline $\begin{array}{l}\text { State } \\
\text { owned }\end{array}$ & 5 & 11.62 & 11.6 & 11.6 \\
\hline $\begin{array}{l}\text { Private } \\
\text { Sector }\end{array}$ & 38 & 88.37 & 88.4 & 100 \\
\hline $\begin{array}{l}\text { FDI } \\
\text { enterprise }\end{array}$ & 0 & 0 & 0 & 100 \\
\hline $\begin{array}{l}\text { Joint } \\
\text { Venture }\end{array}$ & 0 & 0 & 0 & 100 \\
\hline Total & 43 & 43 & 100.0 & \\
\hline
\end{tabular}

In order to be able to rank success factors according to their effect, Her (2013) suggested using mean, but he claimed that we must first test the difference between means statistically through what's called "one sample T-test" . As (sig 2 - tailed) is lower than 0.05 so differences between factors means is significant and it represents the rank of these factors according to their importance and effect. The following table (4) list the results of One sample T-test.

Table 4: One-Sample T-Test

\begin{tabular}{|c|c|c|c|c|c|c|}
\hline \multicolumn{7}{|l|}{ 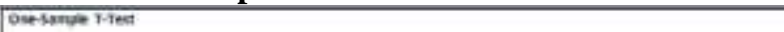 } \\
\hline & \multicolumn{6}{|c|}{ Fervecte.3 } \\
\hline & \multirow[t]{2}{*}{$T$} & \multirow{2}{*}{ 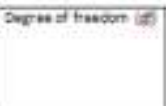 } & \multirow{2}{*}{ 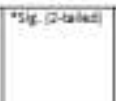 } & \multirow{2}{*}{ Wean Defortas } & \multicolumn{2}{|l|}{ काक } \\
\hline & & & & & Lower & UADE \\
\hline 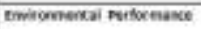 & Is 390 & 49 & & 500000 & .9008 & I.32400 \\
\hline 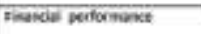 & 120000 & 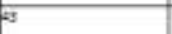 & 5000 & $558 \times 2$ & sat & 20520 \\
\hline 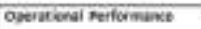 & 22015 & 5 & 000 & 10257 & .900 & 5.1998 \\
\hline Mariven & $203 \pm$ & $=3$ & .000 & $10 \mathrm{mat}$ & wat & 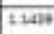 \\
\hline ineermal faton & 1475 & 4 & 800 & FI:A & mis & 5.tatis \\
\hline Movitir & is & $a$ & 900 & 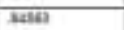 & Trinit & जका \\
\hline Angidicten & 211200 & 49 & 300 & sises & .8502 & 1.0058 \\
\hline intarneir Masagemant & Esat & 25 & 1000 & 2065 & 2027 & 5242 \\
\hline Gevoputiney & Int & ta & $\$ 000$ & 3272 & .324 & .5221 \\
\hline Exporiaion & $2 m$ & 0 & $\infty \infty$ & $90+40$ & inti & 592 \\
\hline 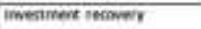 & क्या & 5 & $\infty 00$ & संस्य & क⿻15 & $19 \mathrm{sin}$ \\
\hline Icodongnive & 7254 & 3 & $\$ 00$ & Intza & sint & ant7 \\
\hline
\end{tabular}

* sig at difference > 1.96, Confidence level $95 \%$

\section{E. Reliability of items}

For the reliability test, Crombach Alpha technique was determined using SPSS software for all items in the questionnaire to give a value of 0.879 . After the exclusion of certain questions the Crombach Alpha increased to present higher reliability of 0.901 which still reflects a better acceptable internal consistency reliability where Crombach Alpha represent a high internal consistency reliability with Crombach Alpha coefficient of a scale above 0.7. (See table 5)

Table 5: Composite Reliability

\begin{tabular}{|l|l|}
\hline & Composite Reliability \\
\hline Environmental Performance & 0.8922 \\
\hline Financial Performance & 0.8332 \\
\hline Operational Performance & 0.9411 \\
\hline Practices & 0.8112 \\
\hline Marketing & 0.7511 \\
\hline Regulation & 0.8642 \\
\hline Supplier & 0.8211 \\
\hline Internal factors & 0.8612 \\
\hline
\end{tabular}

\section{E. Validity of items}

Construct validity was also determined through Convergent and discriminate validity which was examined in term of the average variance extracted (AVE) provided by the Smart PLS software (see Table 6) as well as Cross loading of measurement items to latent constructs (Confirmatory factor analysis in path analysis) simultaneously were all the items reflected adequate loadings with value above 0.5 indicating an acceptable level of validity (Helmy, Kortam, \& Abbas, 2012).

\section{Table 6: AVE scores}

\begin{tabular}{|l|c|}
\hline Construct & AVE $^{*}$ \\
\hline Environmental performance & 0.6524 \\
\hline Financial Performance & 0.5144 \\
\hline Operational performance & 0.5239 \\
\hline Marketing & 0.8714 \\
\hline Practices & 0.5448 \\
\hline Regulation & 0.7777 \\
\hline Supplier & 0.6582 \\
\hline Internal factors & 0.6183 \\
\hline
\end{tabular}

$*$ sig at AVE $>0.49$

\section{F. Hypothesis Testing:}

The path analysis being a special case of structural equation modeling (SEM) makes it doesn't assume that the data is normally distributed.

The hypotheses test was interpreted through the value of the T-statistics provided where a $5 \%$ significance level ( $\mathrm{t}$-value: 1.65 ) is used as a statistical decision criterion (see Table 7) (Helmy, Kortam, \& Abbas, 2012).

Table 7: Hypothesis Testing

\begin{tabular}{|l|l|l|l|l|}
\hline Hypothesis & Relationship & $\begin{array}{l}\text { Std. } \\
\text { Error }\end{array}$ & $\begin{array}{l}\text { T- } \\
\text { statistics }\end{array}$ & Decision \\
\hline H1** & $\begin{array}{l}\text { Market \& } \\
\text { GSCM practices }\end{array}$ & 0.0819 & 3.1199 & Supported \\
\hline H2* & $\begin{array}{l}\text { Internal Factors } \\
\text { \& } \quad 0.0743 \\
\text { practices GSCM }\end{array}$ & 1.7609 & Supported \\
\hline H3**** & $\begin{array}{l}\text { supplier GSM } \\
\text { \& G GSC } \\
\text { practices }\end{array}$ & 0.0747 & 5.9007 & Supported \\
\hline H4* & $\begin{array}{l}\text { Regulations } \\
\text { \& GSCM }\end{array}$ & 0.0971 & 1.8571 & Supported \\
\hline
\end{tabular}


Proc. of the Fourth Intl. Conf. Advances in Social Science, Economics and Management Study- SEM 2016 Copyright (C) Institute of Research Engineers and Doctors, USA .All rights reserved.

ISBN: 978-1-63248-094-1 doi: 10.15224/ 978-1-63248-094-1-56

\begin{tabular}{|l|l|l|l|l|}
\hline & practices & & & \\
\hline H5** & $\begin{array}{l}\text { GSCM practices } \\
\text { \& Environmental } \\
\text { erformance }\end{array}$ & 0.0783 & 2.1912 & Supported \\
\hline H6**** & $\begin{array}{l}\text { GSCM practices } \\
\text { \& Financial } \\
\text { performance }\end{array}$ & 0.0607 & 4.1181 & Supported \\
\hline $\mathbf{H 7}^{* * * *}$ & $\begin{array}{l}\text { GSCM practices } \\
\text { \& Operational } \\
\text { performance }\end{array}$ & 0.0660 & 3.5229 & Supported \\
\hline
\end{tabular}

$\left.\right|^{*}$ sig at difference $>1.65$, Confidence level $90 \%$

** sig at difference $>1.96$, Confidence level $95 \%$

$* * *$ Sig at difference $>2.58$, Confidence level $99 \%$

**** Sig at difference $>3.291$, Confidence level $99.9 \%$

\section{x. Findings}

- Governmental regulations and policy options need to consider infrastructure issues such as water and energy resources - excessive subsidies on water and energy need to be eliminated and realistic pricing structures developed so that they serve as (push factors) for industry to practice water and energy conservation, thereby facilitating promotion of GSCM.

- In addition to the pricing structure, suitable fiscal incentives also require to be developed by the government to promote and encourage adoption of GSCM approach.

- Policy options should target provision of subsidy schemes for Small and Medium-sized

- In award GSCM and environmental production strategies are a must, if Egyptian industries are to remain competitive in external markets, as well as in internal markets in the face of increasing pressures of globalization.

\section{xi. References:}

- Allen, H., \& Chia, w. (2010). Critical factors for implementing green supply chain management. Management Research Review, Vol. 33 (No. 6), pp.586 -608 .

- Ali, D., \& Kannan, G. (2010). An analysis of the drivers affecting the implementation of green supply chain management. Elsevier, 5 ( 2), 659-667.

- Arimura, Darnalln, N., \& Katayama, H. (2011). Is ISO 14001 a gateway to more advanced voluntary action? The case of green supply chain management. Journal of Environmental Economics and Management , 61 (1), 170-182.

- Azevedo, G. S., Carvalho, H., \& Machado, V. C. (2011). The influence of green practices on supply chain performance: A case study approach. Transportation Research , 47, 850-871.

- Carter, C. R., Kale, R., \& Grimm, C. M. (2000). Environmental purchasing and firm performance: an empirical investigation. Transportation Research Part E: Logistics and Transportation Review , 36 (3), 219228.
- Chan, R., \& Lau, L. (2001). Explaining green purchasing behavior: a cross-cultural study on American and Chinese consumers. Journal of International Consumer Marketing , 14 ( 2), 9-41.

- Chen, D. J., \& Liang, S. W. (2012). Evaluation of Internal Costs and Benefits for Taiwanese Computer Manufacturers. The Asian Journal oCf oSmhpipuptienrg Manad nLuofgaicsttuicrs , 28 (1), 83-104.

- Diane, M., Hannah, S., Wendy, L. T., \& Monique, U. (2010). Green, lean, and global supply chains. International Journal of Physical Distribution \& Logistics Management , 40 ( 1), 14-41.

- Green, K., Morton, B., \& New, S. (1996). Purchasin and environmenta lmanagement: interactions, plicies and opportunities. Business Strategy and the Environment, 5 (3), 188-197.

- Hassan, M. (2013,). Sustainable Supply Chain Management Practices and Operational Performance. American Journal of Industrial and Business Management , 3 (1), pp. 42-48.

- $\quad$ Saunders, M., Lewis, P., \& Thornhil, A. (2009). Research methods for business students. Edinburgh Gate: Pearson.

- Seitz, M., \& Wells, ,. P. (2006). Challenging the implementation of corporate sustainability: The case of automotive engine remanufacturing. Business Process Management Journal , 12 ( 6), pp. 822-836.

- Sengupta, S., \& Turnbull, J. (1996). Seamless optimization of the entire supply chain. IIE solutions , 28 ( 10), 28

- Sarkis, J. (2003). A strategic decision framework for green supply chain management. Journal of Cleaner Production , 11 (. 4), 397 - 409. 